\title{
以更多更大的科学工作成果來回答 祖國对科学工作者的關怀
}

社論

为了支援社会主义建設, 我國的科学事業必 須大力發展。为了獎謜科学工作者在科学方面辛 勤的創造性劳動, 对前國、对人民所作出的重大 贡献, 今年 8 月, 國务院磉佈了“中國科学院科 学獎金航行条例”。中國科学院並根据这一条例决 定在 1956 年队頒發第一次中國科学院科学獎金。 这是促進我國科学事業梫展的文一重要措施。全 国的科学工作者將因这一条例的頒作和实施而得 到鼓舞, 並在科学研究工作中做出更多、更大的 成績。

中國共生党和人民政府对科学工作者的關怀 是無微不至的。中華人民共和國害法第九十五条 明確規定了: 國家对从事科学事業的公民的創造 性工作, 給以鼓謜和帮趿。新中國建立以來, 由 於社会主义建設事業的開胀, 为我國的科学工作 者開閖了無限廣濶的園地, 大大地推動了我國科

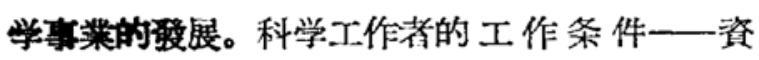
料、回落、儀器、没备、房屋已得到了適当解 决, 並且还在繼續不断地充实中。中國共座党不 倦地以爱國主义思想來鼓愿科学工作者, 並由多 方面都助科学工作者掌揘棓証唯物主义与歷史唯 物主义这一最皮利的理論武器。科学家的物質生 活也得到了保障, 並不断地提高。現在, 國家又

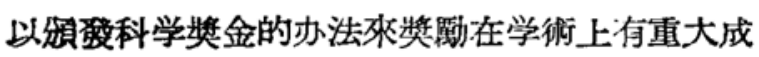
就、对國家建設有重大貢献的科学工作者。解放 前後兩种迥然不同的情况是一个多末强烈的 对 照! 在解放前, 科学工作不被重視; 科学工作者 的辛勤劳動的成果得不到应用; 科学研究的工作 条件十分惡劣; 科学工作者的生活得不到保证。 那样的情况是一去不復返了。从这裹, 我們不 能不粱刻地体会到人民民主國家制度的优越性,

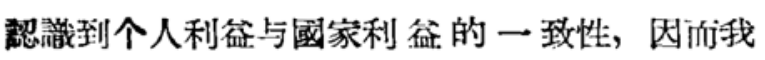

們就不能不進一步提高自己的爱國主义覚俉, 提 高自己为祖國、为人民从事科学研究的栍極性与 創造性。

我們的科学工作是为全國人民刀至全人類課 幸湢的, 一切科学工作都是为了服务於人民、造 福於人民这一崇高的目的的。將中國科学院科学 獎金授予对社会主义建設有重大科学貢献的科学 家, 正体現着國家和人民給予他們以崇高的荣藇 和重大的酬謝。这与资本主义國家的某些所謂“獎 金”、“專利”是有區別的。因为在人民的國家裹, 科学的成就不僅不会被少数人所壟断, 而且由於 獎犕制度的实施, 將得到大量傅播推廣的机会, 便於更有效地为人民服务。

涝联和人民民主國家的科学家及其他國家的 許多正义的科学家, 他們熱爱人民中國, 他們䫝 意以自己的科学工作來帮助我國科学的登展。中 國科学院科学獎金磛行条例規定: “凡外國科学家 从事科学研究或科学著作, 对中華人民共和國科 学的橃塈有重大貢献的……可以授予中國科学院 科学獎金”, 这正是为了对这些先進科学家的薪离 友誼表澾我們的敬意和感謝。

頒發中國科学院科学獎金是一件十分莊麗的

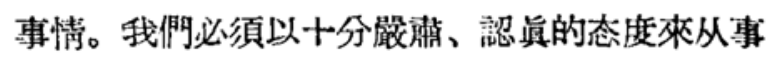
这項工作。我們希望一切負責推荐的机關、学校, 能将全國各个方面在解放後所作出的有價俻的、 具有較高的学術水平的科学研究工作或科学著作 無遺漏地及時推荐出來, 务必使这些工作成坚能 㡅得到評洗的机会。中國科学院科学獎金委員会 則应会同各学部認㫐審查評㴹各机關、学校推萑 的科学工作和科学著作, 根据我國科学工作的实 际情况, 正確地掌㩧标蕉, 务使建國以來在学術 上和对國家建設上貢解最大的科学成能能首先獾 
得中國科学院科学獎金。为了其徹科 学 獎謜 策, 使科学工作者一切有僄值的学術成就都能受 到应有的獎勵, 除做好中國科学院科学獎金的工 作以外，中國科学院的各研究机構和其他業务部

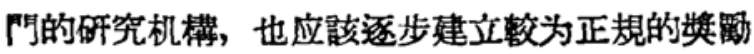

制度, 使我國的科学獎劫制度逐步完善起來。

全國科学工作者們! 为了我國社会主义建設 的勝利，为了回答國家和人民对科学工作者的深 切關怀，坟我們以更高的熱情來从事㓣造性的劳 動, 在科学工作中創造出更多、更大的成紹來!

\section{日本学術会議主席茅誠司給中國科学院}

\section{郭沫若院長的信}

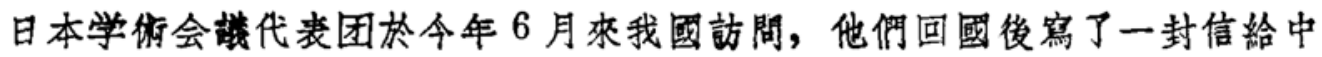
國科学院郭珠若院長。信的原文如下:

中國科学院院長 郭沫若先生:

前电已經奉击一一我門已在 6 月 25 日橫昏平安回抵东京。

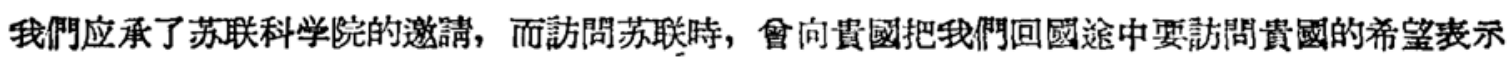
过。哃於这一節, 贵國方面欣然应允, 並且特意以窗客之礼招侍, 这使我阿非常感激。

当時贵科学院正在召開学部成立大会, 百忙之中, 熱烈欢迎, 特設盛篆。在臨別時, 又贈与我們 有意义的紀念品, 連我們的服裝也费了相当的䧄怀。

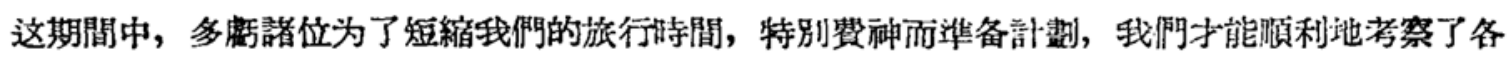
地的研究、数学机構, 工場, 莀莊以及建設工地, 又在博物館、美石館和剧場赛, 也能够看到了具有 長久歴史的贵國文化和藝術。

还有, 陈康白先生以及很多优秀人才担任了招待我們的工作, 同時清年潘㒛睪們以非常流利的日 本話來給我們做了翻譯工作。

其他凡是在贵國所見的朋友們，都以温喛的友情來待我們。这些全給执們一个深刻的憾銘。

目下我們正稨一部考察贵國的報告書, 但我們考察貴國的印象, 从回國当日起, 早已通过各种報 科和廣播傳給全國國民了。今後, 我們一有机会不僅僅对学界, 而且对全國國民, 直卒地傅建走向建 设社会主义國家的貴國的是相, 和我們在貴國所看到、所听到的情形, 同時也努力促進日中兩國的学 㮶交流和友好關係，从学問方面貢献出界和平，以期報答望國的深厚友䛎。

最後，代表全体团員，向贵國表示衰心感謝!

此致

敬勈!

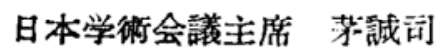

1955 年. 9 月 3 日 